\title{
Analysis and Modification of Scaling Differentiation of Spray Towers in Tianshengqiao Converter Station
}

\author{
Shuyong Guo ${ }^{1, a}$, Feng Zheng ${ }^{2, b}$ and Xueyan $\mathrm{Shi}^{3, \mathrm{c}}$ \\ ${ }^{1,2}$ Tianshengqiao Station, CSG EHV Power Transmission Company, Xingyi, Guizhou, China \\ ${ }^{3}$ Wuhan University, Wuhan, Hubei, China \\ aguoshuyong@163.com, '1145872464@qq.com
}

\begin{abstract}
Keywords: converter valve; spray tower; scaling; valve cooling system.
Abstract. When disassembling and checking the outer cold water pipeline of the third cooling tower in Tianshengqiao Station, we found that the scaling circumstances of the outer cold water pipeline inwall of the $1 \#$ tower, $2 \#$ tower and $3 \#$ tower are very different from that of the radiating coiler. In the 3 cooling towers, the scaling circumstances of $3 \#$ tower and $1 \#$ tower are the most serious and least serious respectively. Hereby, we designed three groups of experiments by selecting the flow of inside circulating water, the flow of spray water and the water resistance in the pipeline as the variables according to the influencing factors of scaling, and then respectively conducted research on the effects of the 3 factors on scaling, and lastly we put forward an improvement scheme for the valve cooling system of Tianshengqiao Station by combining the research conclusions and practical situation.
\end{abstract}

\section{Introduction}

In recent years, the development of the DC power transmission engineering technology is rapid, and valve cooling system in the HVDC system plays a very important role, it will directly threaten the operation of dc system if the valve cooling system appear problems. Spray tower as the valve cooling system in place for heat exchange with the outside cold water and cold water, the scaling problem has always been a problem of field operation. The Tiashengqiao Station put into operation in 2001.[1] TianGuang DC power failure during repair in January 2013,when disassembling the three cooling tower cold water pipe of outside per level in Tianshengqiao Stasion find that 3\# tower cold water pipeline wall scaling is very serious, it leads to flow decreased in 3\# tower cold water which makes the \#3 coil tower scale is very serious. 2\# tower scaling slightly better than $3 \#$ tower , and the scale is very serious, while $1 \#$ tower cold water pipeline wall and amount of scale in cooling coil tube are much less. In this paper, the reason is analyzed, and corresponding experiments and provide reference opinions for future operation.

\section{Converter valve differential analysis of the causes of scale spray system in Tianshengqiao Station}

From water quality analysis of the causes, according to the theory of degree of supersaturation, Langelier saturation index and Ryznar index (stability index), it is concluded that the water scaling ion concentration, temperature and water alkalinity are factors influencing the scale of the water quality. ${ }^{[3]}$ Water quality stability index analysis results in table $1-1$.

From the site conditions, Spray pipe scale differences mainly concentrated in \#2 valve cooling system 1 \#, 2 \#, 3 \# spray tower spray pipe. Making three cooling tower spray pump in the unified pump pit, water pump and the distance of the spray tower is different, the pipe length is not the same, the longer the spraying pipe, pipe scale. Three spray tower spray pipe length from long to short is in turn L3 > L2 > L1, scaling severe situation, in turn, is 1 \# 3 \# $>2$ \# $>$.

The heat exchange coil scale difference is mainly caused by the spray water flow and the difference of circulating water flow. In guarantee under the condition of spray water flow is consistent, if the cold water flow is different, it is that the evaporated water in the cooling tower is 
different. If the cold water flow is big, the concentration ratio will be high and scale will speed up; And cold water flow within guarantee consistent case, if the spray water flow rate, the evaporated water in the cooling tower will be different. ${ }^{[2]}$

Above all, the circulation of spray water flow, the circulating water flow and water pipe resistance lead to the operation condition of the site each are not identical and also lead to the different ion content in the pipeline, the differences between the temperature and pipeline pressure difference, based on this, within the circulating water flow, spray water and pipe water resistance for variables designed three experiments, respectively, to study the effect of three factors on fouling.

Table 1-1 Water quality stability index analysis results of Tianshengqiao Station

\begin{tabular}{|c|c|c|c|c|}
\hline Water samples & $\mathrm{pH}$ & LSI & RSI & conclusion \\
\hline $\begin{array}{c}\text { \#1 Cooling tower water dish } \\
\text { water samples }\end{array}$ & 7.71 & 1.14 & 6.57 & $\begin{array}{c}\text { Water quality of } \\
\text { knot dirty sex }\end{array}$ \\
\hline $\begin{array}{c}\text { \#1 Cooling tower water spray } \\
\text { water }\end{array}$ & 7.71 & 1.16 & 6.55 & $\begin{array}{c}\text { Water quality of } \\
\text { knot dirty sex }\end{array}$ \\
\hline \#2 Spray pool water samples & 7.54 & 1.28 & 6.25 & $\begin{array}{c}\text { Water quality of } \\
\text { knot dirty sex }\end{array}$ \\
\hline Raw water samples & 7.73 & 0.38 & 7.35 & $\begin{array}{c}\text { Mild scaling water } \\
\text { quality }\end{array}$ \\
\hline
\end{tabular}

\section{Converter valve spray tower of Tianshengqiao Station scale difference of the experiment}

This experiment with highly simulation device is to simulate field device. Here are the reasons of designing analog device.

(1) Valve cooling system is related to the normal operation of the converter station, and the experimental process need spray tower stop testing at any time, as a result, the equipment can not meet experimental requirements.

(2)The outer cooling devices of valve cooling system is so large that scale experiments need too much water and the cost of coil cleaning is higher. In order to save costs we do not recommend the use of the equipment.

(3)In site, outer cooling devices of valve cooling system has been used operationally for years, and pipe wall and key components has been dirt or corrosion. It will lead to inaccurate results if still use field devices.

(4)The field devices lack of monitoring instrument and it is unable to real-time monitor the water quality situation, what is more, the transformation cost is too high, therefore, it is not suitable for carrying out experiments.

\subsection{The experiment of circulating water flow distribution}

(1) Repack the coil to the cooling tower and spray pipe after cleaning and weighing them.

(2) Open the valve, and set system for automatic running state.

(3) Start the main circulation pump and adjust the bypass valve to make the flow of the three parallel branch difference value is $0.2 \mathrm{~m}^{3} / \mathrm{h}$ in turn.

(4) Run continuously 7d and stop the device. After close the valve of circulating water, cooling coil will be removed and observed on the surface of the coil scale. We judged the severity scaling by comparing the weight of the coil scale.

(5) We input the results of water quality into input panel and get the results of scaling trend. Then we store the data for analysis.

(6) Decreasing the flow of the spray water continuously and getting 6 sets of test data. Drawing curves to express the relationship about the flow of the cold water and the rate of spray pipe scale. 


\subsection{The experiment of Spray water flow}

(1) Repack the coil to the cooling tower after cleaning and weighing them.

(2) Open the valve, and set system for automatic running state.

(3) Starting the main circulation pump and adjusting the bypass valve to make the flow of the three parallel branch been same, inputting all heater and opening cooling tower fan.

(4) Adjust the spray pump discharge valve, let the flow of three spray loop difference value is 0.2 $\mathrm{m}^{3} / \mathrm{h}$ in turn.

(5) Run continuously 7d and stop the device. Cooling coil will be removed and observed on the surface of the coil scale. We judged the severity scaling by comparing the weight of the coil scale.

(6) We input the results of water quality into input panel and get the results of scaling trend. Then we store the data for analysis.

(7) Decreasing the flow of the spray water continuously and getting 6 sets of test data. Drawing curves to express the relationship about the flow of the spray water and the rate of spray pipe scale.

\subsection{The emulational experiment of pipeline resistance}

(1) Repacking the current limiting ring to the spray pipe after cleaning and weighing them.

(2) Starting the main circulation pump and adjusting the bypass valve to make the flow of the three parallel branch been same, inputting all heater and opening cooling tower fan.

(3) Installing the current limiting ring, respectively, in the way of spray pipe. Adjusting the spray pump valve door to make the flow of three spray water loops equals.

(4) Run continuously 7d and stop the device. Remove the current limiting ring and observe scale on the surface of the ring.

(5) We input the results of water quality into input panel and get the results of scaling trend. Then we store the data for analysis.

(6) Replacing the current limiting ring and continuing to run. After getting 6 sets of test data, drawing curves to express the relationship about the pipeline resistance and the rate of spray pipe scale.

\section{The experimental results and the analysis of conclusion}

\subsection{The experiment of circulating water flow distribution}

From the above analysis: The quantity of the coil in the cooling tower increases with the cold water flow has a tendency to increase. With the increase of cold water flow inside, spray water temperature has a tendency to increase.

Table 3-1 The data of the experiment of circulating water flow distribution

\begin{tabular}{|c|c|c|c|c|c|}
\hline $\begin{array}{c}\text { The flow of } \\
\text { circulating } \\
\text { water L/min }\end{array}$ & $\begin{array}{c}\text { The } \\
\text { temperature } \\
\text { of supply } \\
\text { water/ }{ }^{\circ} \mathrm{C}\end{array}$ & $\begin{array}{c}\text { The } \\
\text { temperature } \\
\text { of } \\
\text { backwater/ } \\
{ }^{\circ} \mathrm{C}\end{array}$ & $\begin{array}{c}\text { The flow of } \\
\text { Spray water } \\
\mathrm{L} / \mathrm{min}\end{array}$ & $\begin{array}{c}\text { The } \\
\text { temperature } \\
\text { of spray } \\
\text { water/ }{ }^{\circ} \mathrm{C}\end{array}$ & $\begin{array}{c}\text { The quality of } \\
\text { the scale /g }\end{array}$ \\
\hline 2 & 40 & 33.4 & 10 & 31.2 & 1.5 \\
\hline 4 & 40 & 33.6 & 10 & 31.6 & 1.6 \\
\hline
\end{tabular}




\begin{tabular}{|c|c|c|c|c|c|}
\hline 6 & 40 & 34.1 & 10 & 32 & 1.6 \\
\hline 8 & 40 & 33.5 & 10 & 32.4 & 1.8 \\
\hline 10 & 40 & 33.4 & 10 & 32.3 & 1.8 \\
\hline 12 & 40 & 34.2 & 10 & 33.5 & 2.2 \\
\hline 14 & 40 & 34 & 10 & 33.1 & 2.4 \\
\hline 16 & 40 & 35.2 & 10 & 34 & 2.5 \\
\hline 18 & 40 & 35 & 10 & 33.6 & 2.8 \\
\hline
\end{tabular}

\subsection{The experiment of spray water flow}

Table 3-2 The data of the experiment of spray water flow

\begin{tabular}{|c|c|c|c|c|c|}
\hline $\begin{array}{c}\text { The flow of } \\
\text { circulating } \\
\text { water I/min }\end{array}$ & $\begin{array}{c}\text { The } \\
\text { temperature } \\
\text { of supply } \\
\text { water } /{ }^{\circ} \mathrm{C}\end{array}$ & $\begin{array}{c}\text { The } \\
\text { temperature } \\
\text { of } \\
\text { backwater/ } \\
{ }^{\circ} \mathrm{C}\end{array}$ & $\begin{array}{c}\text { The flow } \\
\text { of Spray } \\
\text { water } \\
\mathrm{I} / \mathrm{min}\end{array}$ & $\begin{array}{c}\text { The } \\
\text { temperature } \\
\text { of spray } \\
\text { water } /{ }^{\circ} \mathrm{C}\end{array}$ & $\begin{array}{c}\text { The } \\
\text { quality of } \\
\text { the scale } \\
/ \mathrm{g}\end{array}$ \\
\hline 10 & 40 & 38.2 & 2 & 36.5 & 5.4 \\
\hline 10 & 40 & 36.2 & 4 & 35.8 & 5.1 \\
\hline 10 & 40 & 35.8 & 6 & 34.7 & 4.6 \\
\hline 10 & 40 & 34.6 & 8 & 32.4 & 3.8 \\
\hline 10 & 40 & 33.4 & 10 & 31.5 & 3.5 \\
\hline 10 & 40 & 34.2 & 12 & 31.5 & 4.1 \\
\hline
\end{tabular}

From the above analysis: With the increase of the spray water flow, first, the quantity of coil scale increase, and then decrease. In middle has a tendency to decrease. The reason is complicated. On the one hand, the flow of spray water will affect the heat exchange efficiency of cooling tower. On the other hand, flow will affect instantaneous concentration ratio of the spray water on the surface of the heat exchange coil. The former has the appropriate flow when the heat exchange efficiency is best, while concentration ratio will decrease with the increase of flow for the latter. On the whole, there are optimal values for the spray water flow.

\subsection{The emulational experiment of pipeline resistance}

Table 3-3 The data of The emulational experiment of pipeline resistance

\begin{tabular}{|c|c|c|c|c|c|c|}
\hline $\begin{array}{l}\text { The flow of } \\
\text { circulating } \\
\text { water } 1 / \mathrm{min}\end{array}$ & $\begin{array}{l}\text { Temper- } \\
\text { ature of } \\
\text { supply } \\
\text { water } \\
{ }^{\circ} \mathrm{C}\end{array}$ & $\begin{array}{l}\text { Temperat- } \\
\text { ure of } \\
\text { return } \\
\text { water } /{ }^{\circ} \mathrm{C}\end{array}$ & $\begin{array}{l}\text { Flow of } \\
\text { Spray } \\
\text { water } \\
\text { l/min }\end{array}$ & $\begin{array}{c}\text { The } \\
\text { temperature } \\
\text { of spray } \\
\text { water } /{ }^{\circ} \mathrm{C}\end{array}$ & \multirow{2}{*}{\multicolumn{2}{|c|}{$\begin{array}{l}\text { The } \\
\text { emulationa } \\
\text { experiment } \\
\text { of pipeline } \\
\text { resistance }\end{array}$}} \\
\hline 10 & 40 & 35 & 8 & 33.5 & & \\
\hline Project & $\begin{array}{c}D D \\
\mu \mathrm{s} / \mathrm{cm}\end{array}$ & $\mathrm{PH}$ & $\begin{array}{l}\mathrm{T} \\
{ }^{\circ} \mathrm{C}\end{array}$ & $\begin{array}{c}\mathrm{H} \\
\mathrm{mg} / \mathrm{L}\end{array}$ & $\begin{array}{c}\mathrm{B} \\
\mathrm{mg} / \\
\mathrm{L}\end{array}$ & LSI \\
\hline
\end{tabular}




\begin{tabular}{|c|c|c|c|c|c|c|} 
spray water & 654 & 8.42 & 33.4 & 343 & 401 & 1.86 \\
\hline $\begin{array}{c}\text { Bottom } \\
\text { water }\end{array}$ & 653 & 8.42 & 33.4 & 341 & 399 & 1.85 \\
\hline $\begin{array}{c}\text { Differential } \\
\text { pressure of } \\
\text { restrictor ring } \\
/ \mathrm{Pa}\end{array}$ & 500 & 1000 & 1500 & 2000 & 2500 & 22 \\
\hline $\begin{array}{c}\text { Amount of } \\
\text { scale/ mg }\end{array}$ & 42 & 38 & 35 & 24 & 22 & \\
\hline
\end{tabular}

As can be seen from the experimental results: with the differential pressure increasing, the amount of scale decrease. The throttling ability of current limiting ring will be stronger, namely the differential pressure more bigger, the more powerful spray water flushing of the aperture, it's bad for scaling. And the gas partial pressure is small, it's also bad for scaling.

\section{The experimental conclusion}

From the test results as a whole, the biggest influence factor tov scale is the flow of spray water. The key factors of scale is spray water. So the changing flow of the circulating water has small influence to the spray water temperature difference. So we can judge that the biggest influence is the flow of spray water.

It can be seen by the result of the experiment, the difference of spray water flow is derived from the length of the spray pipe, that's the water resistance, different water resistance of the current limiting ring, its port of scaling quantity increases with the decrease of the water resistance, line pressure is smaller, the smaller the gas partial pressure, the more easy to scale.

To sum up, the natural arch on the reason for the difference between the scaling is: due to the spray pipe length differences lead to different spray pipe wall scaling, and with the accumulation of time, the spray water flow gradually produce differences, eventually lead to the surface of the heat exchange coil scale also make a huge difference.

\section{The conclusion}

The Current research data on the diversity of the spray tower scale is not much, so the study should do some test analysis based on the basic principle of scaling. To find out the cause of scale differences and find out the solutions.

\section{The main innovation points of the experiment are:}

(1) A set of valve cooling system have been Designed for water quality inspection , and the scale trend judgement function have been put into PLC to realize automatic judgement of scaling trend .

(2)A method of weight have been adopted for dirty test. A set of independent test unit have been designed to remove scale components directly.

(3) A test apparatus designed that is the same as the valve cooling system in function, made the valve cooling system simulation model realized that is used to study the scaling differences.

\section{To solve the main problem:}

(1)Through research, we have found out reasons of scale difference in spray tour that troubled Tianshengqiao many years and put forward same improvement opinions to prevent the valve cooling system of Tianshengqian as well as those all use the spray tower as external cooling device from scaling .

(2)To develop a set of methods for solving the scaling difference: by re-selection of pumps and pipes, the whole outer cooling system is in balance. Pour water pressure difference coursed by water resistance and smaller flux coursed by scaling have been eliminated, as a result, scale difference decreased. 
(3) The relevant valve cooling system design standards have been developed which including spray pump selection standard, the spray tank layout specification and the valve cooling system of monitoring and control system design specifications, etc. The paper provides a valuable research material for Standardization of valve cold design.

\section{Reference}

[1] Hao Jiangtao, in: Southern Power System Teghnology , edtied by Analysis of Scaling Difference of Spray Towers of the Valve Cooling System in Tianshengqiao Converter Station[J]. 2010,03:99-102.

[2] Zheng Guo-shu, Feng Zhan- wu , in: Guangxi Electric Power ,edtied by Analysisand Modification Unstable Factors of Valve Cooling System in Tianshengqiao Convert Station[J].2010,03:29-31.

[3] Li Guoxing, Jiang Ziqiu, in: Heilongjiang Electric Power, edtied by Requirement and control of internal cooling water quality of convertor valve[J], 2013,06:542-545.

[4] Xie Chenyu,Li Chang. in: www.gdchem.com, edited by The Comparison and Analysis of Water Purification Methods for External Valve Cooling System in Gaopo Converter Station[J], 2015,03:42-108. 